\title{
MODEL PEMBERDAYAAN ASET WAKAF MASJID SECARA PRODUKTIF DI MASJID JOGOKARIYAN YOGYAKARTA
}

\author{
M. Taufiq \\ Mahasiswa S3 Ilmu Hukum PPs FH UII Yogyakarta \\ m.taufiq222@gmail.com \\ Muklisin Purnomo \\ Penyuluh Agama Islam Fungsional Kemenag Kabupaten Bantul \\ mukhlisinberkarya@gmail.com
}

\begin{abstract}
ABSTRAK
Penelitian ini bertujuan mendeskripsikan model pemberdayaan asset wakaf untuk kegiatan produktif di masjid Jogokariyan Mantrijeron Yogyakarta dengan pokok permasalahan melihat bagaimana masjid Jogokariyan menentukan asset yang dianggap memiliki nilai produktif, dan bagaimana cara dan langkah pengelolaannya serta keuntungan apa yang di rasakan oleh masjid maupun jama'ah. Penelitian ini menawarkan perspektif lain tentang pemanfaatan wakaf masjid yang selama ini hanya diperuntukkan untuk keperluan ibadah. Sejarah mencatat bahwa masjid yang dibangun Nabi Muhammad SAW mampu mengemban peran yang multi guna tidak hanya untuk ibadah. Sehingga dengan pemberdayaan asset wakaf Masjid Jogokariyan secara produktif diharapkan dapat meningkatkan ekonomi jama'ah.
\end{abstract}

\section{Kata Kunci : Wakaf Produktif, Masjid Jogokariyan, Pemberdayaan}

Abstract: The study aims to describe the model of waqf assets empowerment for productive activities in Jogokariyan mosque in Mantrijeron Yogyakarta with the main problem that is how the Jogokariyan mosque determines the assets considered to have productive values and how the ways and steps to manage the benefits that could felt by mosque and jamaah are. This research offers another perspective on the utilization of mosque waqf that have been reserved for worship purposes only. The history was noted that the mosque built by Prophet Muhammad was able to assume a multi-use role not only for worship. Therefore, through the empowerment of Jogokariyan mosque waqf assets productively are expected to increase the economy of jamaah.

Keywords: Productive Waqf, Jogokariyan Mosque, Empowerment.

\section{Pendahuluan}

Sejarah mencatat bahwa wakaf sebenarnya telah dikenal dan dilaksanakan oleh umat Islam sejak agama Islam ini berkembang. ${ }^{1} \quad$ Telah diakui menjadi penunjang perkembangan masyarakat Islam, walaupun belum memberikan korelasi yang signifikan bagi pemberdayaan masyarakat. Oleh sebab itu, gerakan wakaf harus menjadi

\footnotetext{
Lihat: Imam Suhadi, Wakaf untuk Kesejabteraan Umat (Yogyakarta: Dana Bhakti Prima Yasa, 2002), hlm. 38; Abd. Ghafur Anshari, Hukum dan Praktek Perwakafan di Indonesia (Yogyakarta: Pilar Media, 2006), hlm. 18
}

garapan utama sebagai instrumen ekonomi agar memberi kontribusi besar bagi kesejahteraan sosial. ${ }^{2}$ Di Indonesia, menurut Muhammad Fuad, pengelolaan wakaf masih jauh dari yang diharapkan, baru lembaga zakat infak dan sedakah (ZIS) yang mulai

\footnotetext{
${ }^{2}$ Edwin Nasution mengatakan bahwa wakaf sebagai instrument ekonomi Islam yang sangat potensial dalam meningkatkan kesejahteraan sosial memiliki peran yang sangat besar dalam membantu menyelesaikan masalah sosia ekonomi masyarakat jika dikelola secara profesional dan produktif. Edwin Nasution, (ed.), "Peran Badan Wakaf Indonesia (BWI) dalam Pengembangan Wakaf di Indonesia" dalam Jurnal al-Awqaf, Vol. 1 No. 1, Tahun 2008, hlm. 1.
} 
terkelola dengan baik yang melibatkan lembaga profesional dan modern. ${ }^{3}$ Ketradisionalan dalam pengelolaan masih tampak, akibatnya-menurut Suhrawardi Lubis-wakaf bukan menjadi produktif tetapi justru memberi beban bagi umat. ${ }^{4}$ Dalam penelitian CSRC (Center for the Study of Religion and Culture) UIN Syarif Hidayatullah terungkap bahwa harta wakaf berupa bangunan yang berdiri di atas tanah wakaf mencapai (87\%), tetapi praktek pembiayaannya paling menonjol bersumber dari masyarakat $(88 \%)$ dan dari hasil wakaf itu sendiri hanya sekitar $9 \% .^{5}$

Sebagian umat Islam memandang bahwa wakaf adalah milik Allah yang tidak boleh diganggu gugat tanpa seizin Allah. Atas pemahaman itu, banyak tokoh masyarakat atau umat Islam tidak merekomendasikan wakaf diberdayakan secara produktif. Terlebih jika harta wakaf tersebut peruntukannya harus digunakan untuk pendirian tempat ibadah baik itu masjid, langgar atau mushola, maka mereka beranggapan bahwa tanah wakaf tersebut hanya boleh digunakan untuk kegiatan ibadah mahdhah saja. Daerah Istimewa Yogyakarta sebagai ikon kota pelajar dengan penduduk muslim sebesar 3.118.827 atau $(91,38 \%$ ) dan persebaran tempat ibadah masjid sebanyak 6.053 buah, langgar 3.588 buah, dan musholla 1.928 buah, sebagian besar dari asset tersebut berdiri di atas tanah wakaf. ${ }^{6}$

Dari sisi pengelolaan masjid pada umumnya juga memprihatinkan. Masih banyak pengurus masjid yang tidak mampu mengoptimalkan peran dan fungsi masjid karena keterbatasan SDM untuk memakmurkan masjid, apalagi memikirkan

3 Muhammad Fuad, Membangunkan Raksasa Tidur Problematika Pengelolaan dan Pendayagunaan Wakaf di Indonesia (Jakarta: Piramedia, 2008), hlm. 2.

4 Suhrawardi K . Lubis, dkk., Wakaf dan Pemberdayaan Umat; (Jakarta : Sinar Grafika, 2010), hlm. 101.

5 Tuti A. Najib, (ed.), Wakaf, Tuban dan Agenda Kemanusiaan Studi tentang Wakaf dalam Perspektif Keadilan Sosial di Indonesia (Jakarta: CSRC UIN Syarif, 2006), hlm. 120.

${ }^{6}$ Data Penamas Kanwil Kementerian Agama Daerah Istimewa Yogyakarta tahun 2011. para jama'ah yang fukara dan masakin di sekitar masjid. Dari tahun ke tahun, jumlah masjid kian bertambah. Tetapi harus diakui dengan jujur, bahwa fungsinya belum maksimal dan optimal. Pemberdayaan asset masjid selama ini, kurang begitu diperhatikan. Padahal masjid mempunyai peran strategis dalam membangun kesejahteraan umat. Masjid selama ini hanya berperan sebatas tempat ibadah shalat ritual semata. Padahal jika masjid itu berdaya, maka masyarakatnya pun akan sejahtera.

Sejarah mencatat bahwa masjid yang dibangun Nabi mampu mengemban peran yang multiguna. Masjid dijadikan pusat atau sentra kegiatan kaum muslimin. Kegiatan di bidang pemerintahanpun mencakup ideologi, politik, ekonomi, sosial, peradilan dan kemiliteran dibahas dan dipecahkan di masjid. Masjid berfungsi pula sebagai pusat pengembangan kebudayaan islam, merupakan tempat halaqah, diskusi, mengaji dan memperdalam ilmu-ilmu pengetahuan agama dan umum. Demikian juga Rasulullah membina para sahabat di masjid dengan memberikan pendidikan dan pengajaran di dalam masjid sehingga masjid berfungsi maksimal sebagai pusat kegiatan apakah menyangkut masalah ukhrawi maupun duniawi. ${ }^{7}$

Masjid paripurna sebagaimana dicontohkan Nabi tersebut nampaknya mampu diterjemahkan secara apik di Masjid Jogokariyan. Tidak mengherankan di kemudian hari masjid ini menjadi prototype masjid percontohan tingkat nasional dan menjadi tujuan studi banding dari berbagai intansi baik dalam negeri maupun luar negeri. Dilihat dari sisi bangunan masjid Jogokariyan bukanlan tergolong masjid yang megah jika dibanding masjid-masjid besar Nusantara lainya, namun, dari sisi pengelolan masjid ini tergolong istimewa. Dalam hal pembiayaan, masjid Jogokariyan telah mampu membiayai kehidupannya tanpa bergatung pada infaq jama'ah. Salah satu cara yang di tempuh adalah dengan memaksimal potensi lahan-

Sofyan Harahap, Manajemen Masjid, (Yogyakarta: Dana Bhakti Prima Yasa, 1993), hlm. 5. 
lahan dan asset yang dianggap bernilai produktif. Sebagian bangunan masjid dijadikan sebagai penginapan VIP sekelas hotel berbintang tiga. Untuk menunjang dan melayani tamu masjid di sediakan jasa catering, dan layanan transportasi.

Untuk menarik perhatian anak-anak muda yang sering nongkrong di pinggirpinggir jalan, masjid menyediakan angkringan di halaman masjid. Keberadaan angkringan mendatangkan berbagai keuntungan baik secara ekonomis, maupun sosiologis. Dari sisi ekonomis, jamaah masjid menjadikan angkringan wahana meningkatkan ekonomi jamaah, dengan menitipkan jajanan. Dari sisi sosiologi, angkringan Masjid Jogokariyan ternyata menjadi tempat yang strategis dalam menyebarkan dakwah Islam. Di angkringan antara ustadz dan jama'ah sering terlibat diskusi keagamaan yang santai tapi efektif. Di saat panggilan shalat menggema, baik pedagang maupun pembeli segera bergegas melaksanakan shalat berjama'ah, tanpa harus menutup dulu angkringannya. Dalam perkembangannya konsep angkringan tersebut mampu berkembang baik dan telah memiliki 9 outlet di beberapa kota besar di Indoneisa dengan konsep yang lebih modern dengan nama "Angkringan Jogja Jogokariyan". 8

Dari beberapa usaha yang dilakukan pengurus masjid Jogokaryan tersebut ternyata mampu membiayai sendiri segala biaya operasional masjid, bahkan bisa memberikan pelayanan sosial bagi masyarakat. Hal itu menjadi menarik untuk digali lebih dalam agar bisa dijadikan inspirasi atau model pemberdayaan asset masjid di tempat lain. Bagaimana menentukan obyek/asset yang dianggap memiliki nilai produktif? Bagaimana cara dan langkah pengelolannya? Keuntungan apa yang di rasakan oleh masjid maupun jama'ah? Pertanyaan itulah yang akan menjadi pintu masuk dalam mengetahui pemberdayaan asset Masjid Jogokariyan dalam meningkatkan ekonomi jama’ah.

\section{Metodologi Penelitian}

8 Wawancara dengan Ustadz Jazir ASP, di depan Islamic Center Masjid Jogokariyan 16 Juni 2017.

\section{Jenis Penelitian}

Jenis penelitian ini adalah adalah peneliitian kualitatif, karena dalam pengumpulan data dan penafsirannya tidak menggunakan angka, ${ }^{9}$ sehingga data yang diperoleh dalam penelitian ini adalah berupa gambaran, gejala, dan fenomena yang terjadi di Masjid Jogokaryan. ${ }^{10}$

\section{Ruang Lingkup Penelitian}

\section{a. Lokasi Penelitian}

Lokasi penelitian ini adalah di Masjid Jogokoriyan Mantrijeron Kota Yogyakarta, namun bukan persoalan masjid secara menyuluruh, tapi hanya meneliti penginapan VIP dan angkringan yang menjadi salah satu usaha pemberdayaan produktif.

\section{b. Subyek Penelitian}

Subyek dalam penelitian ini adalah Takmir Masjid Jogokarya, yaitu: ketua takmir masjid, pedagang angkringan dan biro kerumahtanggaan. Dalam penelitian ini, sampel tidak mewakili populasi dengan dikaitkan pada generalisasi tetapi lebih mewakili informasi untuk kedalaman studi dalam konteksnya. $^{11}$ Sehingga dalam menentukan sampel, peneliti menggunakan teknik purposive sampling, yaitu sample sengaja dipilih, tidak menggunakan random sampling.

\section{Teknik Pengumpulan Data}

Teknik pengumpulan data yang digunakan dalam penelitian ini adalah:

a. Metode Observasi

Dalam penelitian ini mengadakan pengamatan (melihat, mendengar dan bertanya) dan

\footnotetext{
${ }^{9}$ Suharsimi Arikunto, Prosedur Penelitian: Suatu Pendekatan Praktek, Jakarta: PT. Rineka Cipta, 2002, hlm. 10

10 S. Margono, Metode Peneltian Pendidikan, (Jakarta: PT. Rineka Cipta, 2000), hlm. 9.

11 Ibid. hal. 42.
} 
mencatat keadaan yang menggambarkan tentang model pemberdayaan asset masjid secara produktif. ${ }^{12}$

b. Wawancara

Di samping melakuan obeservasi langsung untuk mendapatkan data akurat penulis juga melakukan wawancara. ${ }^{13}$ Sehubungan dengan kebutuhan penelitian ini dalam menggunakan metode interview, peneliti menggunakan beberapa pendekatan interview, yaitu:

1) Interview bebas, yaitu pewawancara bebas menanyakan apa saja, tetapi tetap terikat pada data tentang pemberdayaan asset masjid.

2) Interview terpimpin, yaitu interview yang dilakukan pewawancara dengan membawa sederetan pertanyaan lengkap dan terperinci.

c. Dokumentasi

Peneliti menggunakannya untuk mengetahui dokumen tentang awal mula dan ide pemberdayaan asset masjid Masjid Jogokaryan secara produktif baik berupa bahan tertulis atau gambaran-gambaran penting/film yang mendukung obyektivitas penelitian.

\section{Teknik Analisis Data}

12 Sutrisno Hadi, Metodologi Research Jilid 2, (Yogyakarta: ANDI, 2000), hlm. 136, M. Nazir bahwa observasi adalah cara pengambilan data dengan menggunakan mata tanpa adanya bantuan alat standar lain untuk keperluan tersebut". lihat juga M. Nazir, Metode Penelitian, (Jakarta: Ghalia Indonesia, 1988), hlm.212.

13 Margono menjelaskan bahwa "Wawancara merupakan sebuah alat pengumpul informasi dengan sejumlah pertanyaan secara lisan untuk menjawab secara lisan pula. Lihat, S. Margono, Metode..... hlm. 165. Senada dengan itu, lihat juga, Metodologi Penelitian Kualitatif, (Bandung: PT. Remaja Rosdakarya, 2000), hlm. 5 .
Data yang telah terkumpul diolah dan di analisa dengan menggunakan analisis deskriptif kualitatif, sedang langkah yang ditempuh menggunakan metode Miles dan Heberman, yaitu reduksi data (penyelesaian dan penyederhanaan data), penyajian data, penarikan kesimpulan dan verifikasi hasil. $^{14}$

\section{Tujuan Penelitian}

Secara umum penelitian ini bertujuan mendeskripsikan model pemberdayaan asset wakaf untuk kegiatan produktif di masjid Jogokaryan Mantri Jeron Yogyakarta. Sedang secara khusus penelitian ini bertujuan mendeskripsikan model pemberdayaan asset masjid berupa hotel (penginapan) dan penyediaan lahan untuk pedagang kaki lima (angkringan) yang berada di halaman masjid Jogokariyan.

\section{Masjid Jogokaryan dan Pemberdayaan Aset}

Keberadaan masjid Jogokariyan tidak dapat dilepaskan dari keberadaan kampung Jogokariyan, yaitu sebuah kampung yang terletak di kelurahan Mantrijeron kecamatan Mantrijeron kota Yogyakarta. ${ }^{15}$ Masjid ini berawal dari langgar kecil yang digunakan oleh kalangan terbatas. Gagasan pendirian masjid ini dirintis oleh tokoh agama setempat, antara lain Alm Bapak Zarqoni, Bapak Abdul Manan, Bapak Margono dan Bapak Hadi Sutarno serta sesepuh lainya yang didukung oleh Pengurus Muhammadiyah Ranting Karangkajen. Peletakan batu pertama dimulai pada tahun 1966 dan selesai pada bulan Agustus 1967 dan segera difungsikan, hingga kemudian pada perkembangannya masjid tak mampu lagi menampung berbagai aktifitas jamaah, yang pada akhirnya

14 Munaris, Metode Penelitian (Suatu Pendekatan Proposal). (Jakarta: Bumi Aksara, 1999). hlm. 47-48.

15 Profil Masjid Jogokariyan, dokumen masjid dalam bentuk Compac disk tahun 2015 
mendorong direnovasinya masjid Jogokariyan yang kedua kalinya.

Pada awalnya masjid Jogokaryan dibangun dengan ukuran $9 \times 9 \mathrm{~m} 2$ dan kini setelah mengalami dua kali renovasi masjid tersebut telah berukuran $600 \mathrm{M}^{2}$ bangunan yang ada di masjid jogakriyan terdiri 3 lantai, lantai I untuk lahan parkir dan kantor-kantor, lantai II untuk gedung Islamic Center, sedang lnatai III tiga adalah digunakan untuk membangun penginapan VIP sekelas hotel bintang III sebanyak 11 kamar. ${ }^{16}$

Para pengurus masjid Jogkariyan memiliki gagagasan tentang masjid mandiri. Mereka berpikir bahwa ke depan masjid Jogoariyan harus mandiri, bisa menghidupi keberlangsungan dirinya sendiri. Mereka berpikir bagaimana masjid Jogokariyan tidak menjadi beban bagi masyarakat, tidak boleh bergantung hidup dari sumbangan masyarakat, apalagi sampai mengedarkan proposal kesana kemari, ke depan masjid harus bisa menghidupi masyarakat.

Kegelisahan-kegelisahan tersebut dilanjutkan dengan diskusi dan langkah pencarian data, analisis situasi internal dan eksternal hingga penyusunan rencana dan penyusunan kegiatan. Ada beberapa hal yang menjadi pertimbangan meliputi, kekuatan, kelemahan, peluang, dan ancaman:

Beberapan hal yang dianggap menjadi kekuatan yang terdapat di Masjid Jogokariyan adalah:

a. Kesadaran warga terhadap kemakmuran masjid mulai meningkat, hal itu terbukti setiap waktu shalat shaf masjid selalu penuh.

b. Kepercayaan jamaah terhadap para pengurus tinggi.

c. Banyak jamaah yang ingin membantu keberlangsungan masjid.

Sedang beberapa kelemahan yang dihadapi adalah :

a. Masjid belum mampu menghidupi dirinya sendiri dan masih bergantung pada infaq jamaah.

\footnotetext{
${ }^{16}$ Wahyu Tejo Raharjo, dokumen masjid Jogokariyan
}

b. Masjid belum memiliki usaha yang menjadi penopang masjid

Adapun beberapa peluang yang menjanjikan adalah :

a. Lokasi tanah masjid yang berada di pinggir jalan raya.

b. Keberadaan masjid Jogokariyan telah menjadi brand association yag menjadikan seseorang selalu penasaran ingin berkunjung.

c. Yogyakarta adalah daerah yang kaya akan budaya, bahkan menjadi daerah tujuan wisata utama di Indonesia.

d. Banyak tamu domestic maupun luar negeri yang melakukan studi banding dan belajar tentang pengelolaan masjid.

Di samping peluang yang banyak ternyata terdapat tantangan yang harus dipertimbangkan dalam menentukan langkah pemberdayaan masjid Jogoakaryan yaitu:

a. Tersedianya usaha yang mampu menopang keuangan masjid tapi tidak mematikan potensi perekonomian jamaah.

b. Usaha yang bisa bertahan lama (sustainable ) dan tidak membutuhkan dana yang banyak.

c. Terbukanya lapangan kerja yang bisa diakses oleh jamaah masjid Jogokariyan

d. Tersedianya usaha yang bisa mendukung kegiatan masjid Jogokariyan dari segala arah.

Berdasarkan beberapa alasan di atas menggerakkan seseorang untuk memberikan modal dan meminta masjid mendirikan koperasi maupun supermarket. Namun tawaran tersebut ditolak karena dikhatawatirkan akan mematikan usaha-usaha kelontong yang dimiliki jamaah. ${ }^{17}$ Berdasarkan kajian yang mendalam tehadap pertimbangan di atas pengurus menjadikan peninapan VIP (sekelas hotel bintang tiga) menjadi pilihan usaha yang nantinya diharapkan mampu menopang kehidupan masjid. Di samping itu usaha hotel merupakan bisnis yang sangat

${ }^{17}$ Wawancara dengan Tejo Wahyu Raharjo di Ruang Sekretariat Takmir Masjid Jogokariyan tanggal 16 Juni 2017. 
menguntungkan dan sustainable atau bertahan cukup lama.

Hal itu sesuai dengan visi dan misi yang kembangkan oleh masjid jogokariyan yaitu; "Terwujudnya masyarakat sejahtera lahir batin yang diridhoi Allah melalui kegiatan kemasyarakatan yang berpusat di Masjid" yang kemudian dijabarkan dalam misinya "Menjadikan masjid tempat merujuk berbagai persoalan masyarakat. Visi dan misi tersebut kemudian direalisasikan dalam bentuk progam kerja yaitu Menggali sumber dana yang optimal tanpa harus memberi beban kepada jamaah. ${ }^{18}$

\section{Hotel Masjid Jogokariyan}

Pembangunan hasil adalah realisasi dari perencanaan dan kajian yang mendalam tentang situasi dan kondisi lingkungan masjid. Berdirinya hotel masjid jogokariyan adalah bagian dari pendirian Islamic center. Proses pembangunannya berawal dari pembebasan lahan dan pengumpulan dana pada tahun 2005 dan selesai sampai kurang lebih tahun 2011. Hotel masjid Jogokariyan beroperasi pada tahun 2011.

Hotel ini berada di lantai 3 Islamic Center Masjid Jogokariyan benar terwujud. Hotel dengan 10 kamar berfasilitas bintang 3 ini dilengkapi TV, kamar mandi dalam dan AC di tiap kamarnya. tapi jika tamu menginginkan fasilitas yang lebih bagus, Hotel masjid Jogokariyan juga menyediakan satu kamar VIP dengan fasilitas Double Bed, Kamar mandi dengan air hangat, Bathtub, AC dan TV. Harga yang ditawarkan sangat murah dan terjangkau yaitu sekitar 150-200rb / hari untuk kamar biasa.

Hotel Masjid Jogokariyan dikelola secara sederhana oleh biro Rumah Tangga yang di komandani oleh Bapak Sudiwahyono. Hotel ini mempunyai hanya satu orang karyawan yang mempunyai peran multi fungsi, ia bertugas sebagai resepsionis, cleaning service, kasir, terkadang juga manager. Hotel tidak menyediakan menu makan bagi para tamu layaknya tamu hotel-

dalam lampiran. hotel yang lain. ${ }^{19}$ Strategi ini dipilih karena keberadaan hotel jangan sampai mematikan potensi perekoniman yang ada di sekitar masjid. Tamu yang menginginkan sarapan atau makan, bisa mendapatkan di warung warga di sekitar masjid dengan harga yang terjangkau pula, mulai dari bakso, soto, gudeg, warung padang, sate, susu segar, lotek. Para pedagang tersebut kebanyakan warga binaan masjid masjid Jogokariyan. Dengan demikian jika masjid Jogokariyan mendapatkan kunjungan tamu, para warga juga ikut merasakan berkahnya.

Strategi yang di gunakan masjid jogokariyan dalam memasarkan keberadaaan hotelnya banyak mengandalkan kegiatan public relation yang di bangun oleh masjid Jogokariyan. Upaya yang dilakukan melalui promosi media swaliterasi maupun via medi massa. Masjid Jogokariyan selalu mengirimkan informasi kegiatan secara rutin pada media, membuka situs jejaring sosial internet. Ternyata usaha tersebut cukup efektif dalam rangka mempertahankan brand association di benak masyarakat luas dan memantik rasa keinginan masyarakat luas untuk datang ke masjid Jogokariyan. Keadaan itu tentu saja sangat menguntungkan keberdaaan hotel. jika tamu yang datang dari luar kota, setelah melakukan studi banding selalu memutuskan untuk menginap di hotel, sebagaimana di ceritakan seorang tamu dari Makassar ketika bertemu dengan penulis. ${ }^{20}$

Dari usaha penginapan VIP yang dijalankan nyatanya mampu mendatangkan keuntungan secara ekonomis. Pendapatan bersih yang diperoleh dari pengelolaan tingkat hunian Hotel Masjid Jogokariyan ratarata berada pada kisaran 6 juta hingga 15 juta rupiah perbulan. Angka tersebut merupakan nominal bruto, belum termasuk biaya-biaya operasional seperti gaji karyawan, listrik, dan

19 Hasil wawancara dengan Sudiwahyono pengurus takmir Biro Rumah tangga tanggal 18 Juni 2017

20 Hasil Wawancara dengan dr. Whela, seorang dokter spesialis urologi dan pengusaha alatalat kesehatan dari Makassar yang menginap di Hotel Masjid Jogokariyan selama 4 hari. 
lain-lain. $^{21}$ Meskipun masih tergolong kecil, tapi telah mampu membantu dana pengelolaan masjid yang mencapai 15 juta perbulan, membantu biro-biro yang lain dalam melaksanakan kegiatan, bahkan ada yang digunakan untuk kesejahteraan jamaah.

Laporan keuangan hotel menjadi satu dalam laporan keungan biro kerumahtanggaan masjid Jogokariyan dan dilaporkan setiap bulan. Laporan tersebut dibuat untuk memberikan informasi kepada para jamaah maupun masyarakat umum. Laporan yang dibuat pengelola hotel sifatnya masih sangat sederhana yaitu pencatatan harian yang disusun secara histories untuk memberikan informasi jumlah kas yang dimiliki oleh biro kerumahtanggaan. Laporan tersebut hanya terdiri dari tanggal transaksi, jenis transaksi, debet, kredit dan kas.

Laporan tersebut dibuat dalam rangka menjaga amanat masyarakat sekaligus sebagai sarana pengawasan (controling) dan evaluasi terhadap kinerja pengelola hotel (biro kerumahtanggaan). Dalam system manajemen masjid Jogokariyan, masyarakat adalah pemilik otoritas tertinggi, sehingga masyarakatlah yang juga harus mengontrol terhadap pengelola agar berjalan dengan baik. Pengelola masjid Jogokariyan selalu mendorong jamaah terjadinya system social yang melibatkan partisipasi banyak kalangan. Jamaah diperbolehkan memberikan evaluasi, kritik dan masukan yang membangun demi kebaikan masjid Jogokariyan. $^{22}$

Keuntungan yang didapatkan dari pengelolaan peninapan VIP di masjid Jogokariyan tidak sebesar yang didapatkan hotel-hotel pada umumnya, namun ada efek domino yang bernilai ekonomis akibat keberadaan Hotel dan Islamic Center ada layanan transportasi, wisata, wedding organizer, dan catering yang dikelola oleh masjid Jogokariyan. Salah satu usaha yang juga merupakan bagian yang tidak bisa

21 Wawancara dengan bapak Sudiwahyono, Biro Rumah Tangga Masjid Jogokariyan tanggal 18 Juni 2017.

22 Hasil Wawancara dengan Ust. H. Jazir ASP, tanggal 15 Juni 2017 di Depan Hotel Masjid Jogokaryan dilepaskan adanya hotel adalah Angkringan yang berada di halaman Masjid Jogokariyan tepatnya berada dipintu masuk hotel.

\section{Angkringan Masjid Jogja}

Angkringan adalah usaha non profit, karena keberadaan angkringan adalah salah satu bentuk pelayanan masjid Jogokariyan terhadap jamaah. Kebijakan menyediakan angkringan didasari atas berbagai alasan seperti:

a. Menyediakan tempat nongkrong bagi para remaja dan pemuda, agar lebih mudah terkontrol.

b. Menyediakan kebutuhan makan agar lebih lama tinggal di masjid. Karena sering kali pada waktu maghrib jamaah pulang hanya beralasan minum, dengan adanya kangkringan kebutuhan tersebut tercukupi.

c. Menyediakan kebutuhan makan tamu hotel sambil menikmati suasana kampong Jogokaryan.

d. Menciptakan suasana agar tetap hidup, karena masjid jogokariyan buka selama 24 jam.

Menu yang disediakan tidak berbeda jauh dengan angkringan lainnya seperti Nasi Kucing (yang dalam bahasa Jawa disebut Sego Kucing). Biasanya lauk pauk seperti tempe sambal kering, teri goreng, sate telur puyuh, sate usus, sate ceker, dan ikan bandeng menjadi menu tambahan. Sedangkan untuk minuman yang disediakan seperti wedang jahe, susu jahe, teh manis, air jeruk dan kopi. Pedagang angkringan didatangkan dari para jamaah masjid yang bersedia berdagang di lahan yang dipersiapkan. Masjid menyediakan tempat, air penerangan dan kursi-kursi.

Angkringan yang berada di Halaman Masjid Jogokaryan ini dikelola oleh 3 orang, yaitu Joko, Rosyid, dan Kembar semua merupakan warga sekitar masjid Jogokaryan. Sistem penjadwalan dalam sebulan di bagi menjadi 3 secara bergilir, sehingga setiap orang mendapat giliran 10 hari. Dalam sehari di bagi menjadi 2 sift, sift pertama pagi antara jam 06.10 sampai jam 13.00, sedang sift ke II jam 13.00 sampai malam. Semua pengaturan 
tersebut dikelola oleh biro rumah tangga Masjid Jogokariyan. ${ }^{23}$

Jika menggunakan kalkulasi untung rugi, adanya angkingan di halaman masjid tersebut, sebenarnya tidak mendatangkan keuntungan secara langsung, atau bisa dikatakan dari sisi bisnis masjid Jogokariyan sebenarnya rugi karena masjid telah memfasilitasi pedagang berupa tempat berdagang yang strategis, menyediakan air yang berlimpah, penerangan yang cukup, membuatkan anjungan yang nyaman, sebaliknya pedagang tidak ditarik retribusi uang sepeserpun, alias gratis. Padahal ratarata setiap pedagang yang berdagang di tempat tersebut sekali mangkal, bisa mendapatkan keuntungan bersih Rp. 150.000, 00 hingga Rp. $250.000,00 .^{24}$ Di samping rugi, keberadaan angkringan dari sisi estetika juga sangat mengganggu, tapi nyatanya angkringan tetap di pertahankan.

Meskipun system kelola yang di terapkan masjid dalam mengelola angrkingan adalah non profit, namun dari sisi pemberdayaan ekonomi jamaah langkah tersebut ternyata cukup strategis dan efektif. Jamaah yang lain yang tidak berdagang bisa menitipkan daganganya di angkringan. Para pedagang secara tidak langsung memiliki rasa hutang budi kepada masjid, yang pada akhirnya mereka akan mengajak keluarga mereka untuk selalu datang ke masjid dan menghidupi masjid.

Keberadaan angkringan yang berada di halaman masjid ternyata menjadi semacam madrasah, karena ternyata para pelangan sering melakukan diskusi dan bertanya kepada para ustad tentang keagamaan tanpa ada rasa canggung.

Dalam perkembangannya gagasan tersebut tersebut mampu berkembang pesat dan telah membuka 9 outlet di beberapa kota besar di Indoneisa dengan konsep yang lebih modern dengan nama "Angkringan

\footnotetext{
23 Wawancara dengan bapak Rusydi Harminto; salah satu pengurus takmir Masjid Jogokaryan pada tanggal 13 Juni 2017.

24 Wawancara dengan Joko, pedagang angkringan masjid Jogokariyan pada tanggal 12 Juni 2017.
}

Jogja". Outlet tersebut berada di Kupang, Semarang, Gresik, Jakarta, Bandung, Makasar, Medan, Malang, Surabaya.pihak masjid hanya menjual konsepnya, dan pihak pengelola harus menyediakan ustadz yang berkompeten, mengalokasikan dana CSR untuk pengembangan masjid.

\section{Analisis Terhadap Pemberdayaan Asset Masjid Jogokariyan}

Pengurus masjid menyadari bahwa masjid yang merupakan wakaf dari masyarakat, harus memberikan manfaat secara maksimal baik bagi waqif, nadhir maupun manquf alaih (masyarakat). Hal itu sesuai dengan Amanat UU No. 41 tahun 2004 tentang Wakaf yang mengamanatkan bahwa selain untuk kepentingan ibadah mahdhah, juga menekankan perlunya pemberdayaan wakaf secara produktif untuk kesejahteraan Sosial. ${ }^{25}$ Dalam penjelasannya disebutkan :

"Peruntukan benda wakaf tidak sematamata untuk sarana kepentingan ibadah dan sosial melainkan diarabkan pula untuk mewnjudkan kesejabteraan umum dengan cara meningkatkan potensi dan manfaat ekonomi benda wakaf. Hal ini memungkinkan pengelolaan benda wakaf dapat memasuki wilayah kegiatan ekonomi dalam arti luas sepanjang pengelolaan tersebut sesuai dengan prinsip-prinsip manajemen dan ekonomi Syari'ah. ${ }^{, 26}$

Mereka juga berkomitmen bahwa masjid harus mandiri dan bisa mencukupi kebutuhannya sendiri tanpa harus bergantung

25 Ahmad Djunaidi dan Thobieb al-Asyhar, Menuju Wakaf Produktif; sebuah upaya Progresif untuk Kesejateraan Umat, (Jakarta: Mitra Abadi Press, 2005), Hlm. 90

26 Penjelasan ini sejalan dengan ketentuan pasal 22 UU No. 421 Th 2004 tentang Wakaf, yang menyebutkan: Dalam rangka mencapai tujuan dan fungsi wakaf, harta benda wakaf hanya diperuntukkan bagi : a. sarana ibadah; b. sarana dan kegiatan pendidikan serta kesehatan; c. bantuan kepada fakir miskin, anak terlantar, yatim piatu, bea siswa; d. Kemajuan dan peningkatan ekonomi umat; dan/atau e. kemajuan kesejahteraan umum lainnya yang tidak bertentangan dengan syari'ah dan peraturan perundang-undangan. 
dari infaq jamaah. Masjid harus memiliki usaha yang mampu menjadi fund raising dalam menopang kegiatannya. Hotel dianggap sebagai salah satu usaha yang tepat.

Keputusan para pengurus masjid Jogokariyan menjadikan hotel sebagai salah satu usaha produktif masjid Jogokariyan tidak terlepas dari slogan masjid Jogokariyan "Dari Masjid Membangun Umat". Kajian terhadap situasi internal dan eksternal atau lebih dikenal dengan istilah (SWOT; strength (kekuatan), Weakness (kelemahan), Oppurtunity (kekuatan), dan Threat (ancaman) adalah dasar yang dijadikan pedoman dalam menentukan program pemberdayaan lahan masjid Jogokariyan.

Hotel dikelola sendiri oleh biro kerumahtanggan Masjid Jogokariyan dengan model al-ijarah (operational lease), yaitu akad pemindahan barang atau jasa, melalui pembayaran upah sewa, tanpa diikuti dengan pemindahan kepemilikan (ownership/milkiyyah) atas barang itu sendiri. Dengan kata lain alijarah yang dimaksudkan disini adalah ijarab al-amwal. ${ }^{27}$ Pemakai menyewa kamar sesuai kebutuhan mereka dan membayar sewa kamar sesuai dengan ketentuan telah ada atau tergantung dari kesepakatan ketika terjadi transaksi.

Keberadaan hotel Jogokariyan terbukti telah mampu menjadi fundraising yang dapat menopang dana operasional masjid Jogokariyan, bahkan mampu memberikan subsidi kepada biro-biro lain yang ada di masjid Jogokariyan yang tidak mampu mencukupi pendanannya dalam melaksanakan kegiatan. keberhasilan tersebut menjadi dana-dana infak yang masuk ke masjid bisa langsung dikembalikan untuk kesejahteraan masyarakat sekitar yang membutuhkan.

Laporan keuangan pengelolaan memang masih tergong sederhana karena berisi arus kas (cash flow), padahal semestinya laporang keuangan yang dibuat harus terdiri dari laporan neraca dan perhitungan laba rugi dan laporan perubahan modal yang berisi

27 Muhammad Syafi'i Antonio, Bank Syari'ah dari Teori ke Praktik, Jakarta: Gema Insani Press dan Tazkia Cendekia, 2001), hlm. 117. informasi tentang prestasi hotel yang dikelola sebagai dasar penentapan kebijakan pda tahun yang akan datang. Laporan keungan yang dibuat paling tidak harus mencakup tiga hal ; arus kas (chas flow), neraca keuangan (balance sheet), laporan laba rugi (income statement.$^{28}$

Meski demikian usaha yang ditempuh oleh pengelola asset Masjid Jogokariyan agar lebih produktif (hotel) perlu mendapat apresiasi yang tinggi, sebab sudah sangat mencerminkan nadhir wakaf professional, karena memenuhi tiga aspek; transparansi, public accountability (pertanggungjawaban umum), dan aspiratif (maus mendengar dan mengakomodasi seluruh dinamika kenadhiran). ${ }^{29}$

Laporan tersebut dibuat dalam rangka menjaga amanat masyarakat sekaligus sebagai sarana pengawasan (controling) dan evaluasi terhadap kinerja pengelola hotel (biro kerumahtanggaan). Dalam system manajemen masjid Jogokariyan, masyarakat adalah pemilik otoritas tertinggi, sehingga masyarakatlah yang juga harus mengontrol terhadap pengelola agar berjalan dengan baik. Pengelola masjid Jogokariyan selalu mendorong terjadinya system social yang melibatkan partisipasi banyak kalangan. Jamaah diperbolehkan memberikan evaluasi, kritik dan masukan yang membangun demi kebaikan dan kemakmuran masjid Jogokariyan

Keberhasilan mengelola asset masjid menjadi lebih produktif tidak bisa dilepaskan adanya kekuatan brand association yang telah mengakar bahwa masjid Jogokariyan adalah masjid paripurna, menjadikannya sebagai salah satu tujuan wisata religius. Citra tersebut tidak bisa dilepaskan dari peran public relation yang di bangun oleh masjid

28 Lihat Manajemen Pengelolaan Proyek percontohan Wakaf Produktif, (Jakarta: Kementerian Agama RI; Direktorat Jederal Bimbingan Masyarakat Islam: Direktorat Pemberdayaan Wakaf, 2011), hlm. 105-118

29 Panduan Pemberdayaan Tanah Wakaf Produktif Strategis di Indoenesia Jakarta: Proyek Peningkatan Pemberdayaan Wakaf, Direktorat Jenderal Bimas Islam dan Penyelenggara Haji, Departemen Agama RI, 2004), hlm. 98-99 
Jogokariyan yang berjalan dengan bagus. Upaya yang dilakukan melalui promosi media swaliterasi maupun via medi massa. Masjid Jogokariyan selalu mengirimkan informasi kegiatan secara rutin pada media, situs jejaring sosial internet. Hal ini sesuai dengan fungsi public relation yang mempunyai fungsi timbal balik, ke luar ke dalam. Ke luar ia selalu berusaha menumbuhkan sikap dan gambaran masyarakat yang positif terhadap segala tindakan dan kebijakan organisasi. Ke luar berusaha mengenali, dan mengidentifikasi hal-hal yang menimbulkan sikap dan gambaran negatif (Kurang menguntungkan) dalam masyarakat sebelum sesuatu tindakan dijalankan.

\section{Kesimpulan}

Untuk meningkatkan kemanfaatan benda wakaf, tidak bisa tidak, harus dijalankan dengan melakukan kegiatan ekonomi. Karena wakaf merupakan bagian dari Syari'ah Islamiyah, maka kegiatan ekonomi dalam pengelolaan benda wakaf tidak boleh bertentangan dengan ketentuanketentuan dalam wakaf itu sendiri dan prinsip-prinsip dalam ekonomi Syari'ah. Sudah saatnya para nadhir wakaf melakukan langkah yang mengarah pada produktifitas tanah wakaf yang ada, supaya dapat mendatangkan kemanfatan kepada semua pihak, baik bagi wakif maupun manquf alaih (masyarakat). Sehingga dalam penelitian ini penulis dapat menarik beberapa kesimpulan.

Pertama, pemberdayaan asset masjid Jogokariyan berangkat dari sebuah prinsip "Dari Masjid Membangun Umat. Keberadaan masjid yang merupakan wakaf warga tidak boleh membebani warga. Masjid harus memiliki fund raising yang mampu membiayai dana operasional masjid. Kedua, penginapan VIP dan Angkringan adalah hasil kajian yang diawali dari kajian terhadap situasi dan kondisi lingkungan masjid Jogokariyan. Kedua jenis pemberdayaan tersebut dianggap tepat karena tidak akan mematikan berbagai usaha yang telah dikembangkan oleh jamaah binaan masjid. Usaha yang dijalankan harus mampu membantu meningkatkan perekonomian jamaah. Ketiga, meskipun dari sisi keuntungan yang didapatkan dari pemberdayaan asset masjid masih tergolong kecil, dan hanya cukup untuk membiayai operasional masjid, namun ada keuntungan lain yang lebih besar dan lebih bermanfaat jika dibandingkan dengan hasil materi yang didapatkan. Kehidupan jamaah lebih sejahtera, ekonomi meningkat, dana infaq yang masuk ke masjid bisa digunakan untuk pemberdayaan dan kesejahteraan jamaah.]

\section{DAFTAR PUSTAKA}

Anshari, Abd. Ghafur. Hukum dan Praktek Perwakafan di Indonesia, Yogyakarta: Pilar Media, 2006.

Antonio, Muhammad Syafi'i. Bank Syari'ah dari Teori ke Praktik, Jakarta: Gema Insani Press dan Tazkia Cendekia, 2001.

Arikunto, Suharsimi. Prosedur Penelitian: Suatu Pendekatan Praktek, Jakarta: PT. Rineka Cipta, 2002.

Data Penamas Kanwil Kementerian Agama Daerah Istimewa Yogyakarta tahun 2011

Djunaidi, Ahmad. dan Thobieb al-Asyhar, Menuju Wakaf Produktif; sebuah upaya Progresif untuk. Kesejateraan Umat, Jakarta: Mitra Abadi Press, 2005.

Fuad, Muhammad. Membangunkan Raksasa Tidur Problematika Pengelolaan dan Pendayagunaan Wakaf di Indonesi, Jakarta: Piramedia, 2008.

Hadi, Sutrisno. Metodologi Research Jilid 2, Yogyakarta: ANDI, 2000.

Manajemen Pengelolaan Proyek percontohan Wakaf Produktif, Jakarta: Kementerian Agama RI; Direktorat Jederal Bimbingan Masyarakat Islam: Direktorat Pemberdayaan Wakaf, 2011.

Miftahorrman. "Fungsi Organiæing dalam Pengembangan Dakwah", skripsi tidak diterbitkan, Yogyakarta: UIN Sunan Kalijaga, 2008

Moleong, Lexy J. Metodologi Penelitian Kualitatif, Bandung: PT. Remaja Rosdakarya, 2000.

Munaris, Metode Penelitian (Suatu Pendekatan Proposal, Jakarta: Bumi Aksara, 1999. 
Panduan Pemberdayaan Tanah Wakaf Produktif Strategis di Indoenesia, Jakarta: Proyek Peningkatan Pemberdayaan Wakaf, Direktorat Jenderal Bimas Islam dan Penyelenggara Haji, Departemen Agama RI, 2004.

Najib, Tuti A. (ed.), Wakaf, Tuban dan Agenda Kemanusiaan Studi tentang Wakaf dalam Perspektif Keadilan Sosial di Indonesia, Jakarta: CSRC UIN Syarif, 2006.

Nasution, Edwin. (ed.), "Peran Badan Wakaf Indonesia (BWI) dalam Pengembangan Wakaf di Indonesia" dalam Jurnal alAwqaf, Vol. 1 No. 1, 2008.
Nazir, M. Metode Penelitian, Jakarta: Ghalia Indonesia, 1988.

S. Margono, Metode Peneltian Pendidikan, Jakarta: PT. Rineka Cipta, 2000..

Sofyan Harahap, Manajemen Masjid, Yogyakarta: Dana Bhakti Prima Yasa, 1993

Suhadi, Imam. Wakaf untuk Kesejabteraan Umat, Yogyakarta: Dana Bhakti Prima Yasa, 2002.

Suhrawardi K. Lubis, dkk., Wakaf dan

Pemberdayaan Umat, Jakarta : Sinar Grafika, 2010. 